\title{
The Impact of Iron Overload on Transplant-Related Complications and Prognosis of Acute Leukemias
}

\author{
Umit Y. MALKAN, Gursel GUNES, Eylem ELIACIK, Ibrahim C. HAZNEDAROGLU, Okan YAYAR, \\ Sezgin ETGUL, Tuncay ASLAN, Seda AYDIN, Hakan GOKER, Haluk DEMIROGLU, \\ Nilgun SAYINALP, Osman I. OZCEBE, Salih AKSU, Yahya BUYUKASIK
}

Hacettepe University Faculty of Medicine, Department of Internal Medicine, Division of Hematology, Ankara, TURKEY

\begin{abstract}
The impacts of serum iron parameters and/or radiological evidence of systemic iron overload on the prognosis of hematopoietic stem cell transplantation (HSCT) in acute leukemia are controversial. Unfortunately, some of the studies evaluating iron overload in transplant setting did not precisely show the patients with iron overload, mainly due to ignoring consideration of transferrin saturation along with hyperferritinemia for elimination of non-iron overload etiologies of hyperferritinemia. The aim of this study is to assess the effect of iron overload on transplantation related complications and prognosis in acute leukemia. Patients who undergone allogeneic HSCT for acute leukemia in Hacettepe University Medical School Department of Hematology were screened retrospectively in order to find cases with serum iron tests within 9 months before transplant. The endpoints investigated were overall and disease-free survivals, acute and chronic graft-versus-host disease and veno-oclussive disease (VOD). There were 84 patients suitable for inclusion. When various ferritin plus transferrin saturation (TS) cut-off values were investigated for a possible relationship with major transplant-related complications/results only ferritin $>2000$ plus TS> 45\% was found to have an association with VOD at borderline significance ( $p=$ 0.067). In conclusion, we observed a non-significant borderline relationship between iron overload and post-transplant VOD. We did not confirm other post-transplant complications reported in the literature. It must be noticed that although many studies intended to investigate the relationship between iron status and transplant outcomes, only a few of them have really looked for the effect of iron overload.
\end{abstract}

Keywords: Iron overload, Acute leukemia, Transplantation

ÖZET

Akut Löseminin Prognozu ve Transplantasyonla ílişkili Komplikasyonlarına Demir Yükselmesinin Etkisi

Serum demir parametrelerinin ve/veya radyolojik olarak saptanan sistemik demir yüklenmesinin, kök hücre nakli (KHN) yapılmış akut lösemi hastalarının prognozuna olan etkisi tartışmalıdır. Ne yazık ki, demir yüklenmesinin transplantasyona olan etkisini araştıran bazı çalışmalarda demir yüklenmesi olan hastalar doğru bir şekilde saptanamamıştır. Bunun nedeni hiperferritineminin demir yüklenmesi dışındaki sebeplerinin göz ardı edilmesidir. Bu çalışmanın amacı, demir yüklenmesinin akut lösemi hastalarının prognozuna ve transplantasyon ile ilişkili komplikasyonlarına olan etkisinin araștııımasıdır. Transplantasyon öncesi dokuzuncu aya kadar olan serum demir testleri olan hastaları bulmak amacıyla, Hacettepe Üniversitesi Tıp Fakültesi Hematoloji Departmanı'nda allojenik KHN yapılan hastalar retrospektif olarak taranmıştır. Çalışma sonlanım noktaları, genel ve hastalıksız sağkalım süreleri, akut ve kronik graft versus host hastalığı ve venookluziv hastalıktır ( $\mathrm{VOH}$ ). Çalışmaya alınma kriterlerine uyan 84 hasta mevcuttu. Transplant ilişkili komplikasyonlar ile demir yüklenmesi arasında bir ilişki bulabilmek amacı ile transferrin satürasyonu (TS) ve ferritinin değişik eşik değerleri araştırılı. Sadece ferritin> 2000+TS> \%45 olan hasta grubu ile VOH gelişimi arasında sınırda anlamlılık saptandı ( $p=0.067)$. Sonuç olarak, biz bu çalışmada demir yüklenmesi ve transplantasyon sonrası VOH arasında anlamlı olmayan sınırda bir ilişki saptadık. Literatürde saptanan diğer transplantasyon sonrası komplikasyonlar bizim çalışmamızda saptanmadı. Vurgulamak gerekir ki, birçok çalışma demir yüklenmesi ile transplantasyon sonuçları arasındaki ilişkiyi araştırmayı amaçlasa da ancak birkaç tanesinde demir yüklenmesinin etkisi doğru bir şekilde araştırılabilmiştir.

Anahtar Kelimeler: Demir yüklenmesi, Akut lösemi, Transplantasyon 


\section{INTRODUCTION}

The impacts of serum iron parameters and/or radiological evidence of systemic iron overload on the prognosis of hematopoietic stem cell transplantation (HSCT) in acute leukemia are controversial. ${ }^{1,2}$ Patients with hematologic malignancies commonly have an elevated serum ferritin prior to HSCT. However, the relationship between serum ferritin and parenchymal iron overload in leukemic patients may not be correlated. ${ }^{3}$ Nevertheless, albumin, ferritin, and peripheral blood counts broadly capture health status in patients undergoing allogeneic HSCT. ${ }^{4}$

Iron overload or hyperferritinemia irrespective of body iron status may have detrimental effects on the transplantation procedures..$^{5-8}$ Iron overload is associated with free radical generation leading to tissue damage. ${ }^{9}$ There is also a possibility that the adverse prognostic impact of pre-transplant hyperferritinemia might be ascribed to other precipitating factors in addition to the iron overload. ${ }^{10-14}$ Reduced intensed toxicity conditioning regimens may attenuate the impact of iron overload related end-organ toxicity when compared to the myeloablative conditioning. ${ }^{15-18}$ Iron overload may predispose to a higher rate of infections associated with transplantation. ${ }^{19-23}$ Stem cell sources, distinct diseases and different protocols may also affect the impact of iron overload on the process of transplantation. ${ }^{24-28}$ Unfortunately, some of the studies evaluating iron overload in transplant setting did not precisely show the patients with iron overload, mainly due to ignoring consideration of transferrin saturation along with hyperferritinemia for elimination of non-iron overload etiologies of hyperferritinemia (Table 1). Consequently, there are limited (and conflicting) data on the effect of adequatelydefined iron overload on prognosis of allogeneic HSCT. The aim of this study is to assess the effect of iron overload on transplantation related complications and prognosis in acute leukemia.

\section{PATIENTS AND METHODS}

Patients who undergone allogeneic HSCT for acute leukemia between years 2004-2014 in Hacettepe University Medical School Department of Hematology were screened retrospectively in order to find cases with serum iron tests within 9 months before transplant. Serum iron (SI), total iron binding capacity (TIBC) and ferritin levels had been measured. TS was calculated by dividing SI level to TIBC. Serum iron tests compatible with iron loading were defined as association of elevated TS $(>45 \%)$ and ferritin $(>500 \mathrm{ng} / \mathrm{ml})$ levels. Various elevated ferritin and transferrin saturation cut-offs were evaluated for a possible association with clinical endpoints. The endpoints investigated were overall and disease-free survivals, acute and chronic graft-versus-host disease (GVHD) and veno-occlusive disease (VOD). Exclusion criteria included less than complete remission of acute leukemia and chronic or acute liver diseases or other important co-morbidities which are expected to affect serum iron tests, veno-occlusive or GVHD risks. Patients with serum iron tests that had been measured within 1 month before any infectious/inflammatory condition were also excluded. Donors were HLA full-matched siblings and stem cell source was peripheral blood in all patients. For GVHD prophylaxis cyclosporine A (CsA) (3 mg/kg/day iv) and methotrexate (MTX) $(10 \mathrm{mg} / \mathrm{kg} /$ day iv on days 1 , $3,5,11)$ were started. CsA was started on the day 0 with the target blood level of $200-300 \mathrm{ng} / \mathrm{mL}$ and it was tapered after second months of transplantation according to GVHD status of the patient. The conditioning regimens were busulfan/fludarabine/antithymoglobulin (BU/Flu/ATG) in 40 (BU: $0.8 \mathrm{mg} /$ $\mathrm{kg} /$ day intravenously [iv], Flu: $50 \mathrm{mg} / \mathrm{m}^{2} /$ day iv, ATG: $5 \mathrm{mg} / \mathrm{kg} /$ day iv, melphalan/fludarabin (Mel/ Flu) and its variants in 17 (Mel: $140 \mathrm{mg} / \mathrm{m}^{2} /$ day iv, Flu: $50 \mathrm{mg} / \mathrm{m}^{2} /$ day iv), total body irradiation-based (TBI-based) regimens in 11, busulfan/cyclophosphamide (BU/Cy) (BU: $0.8 \mathrm{mg} / \mathrm{kg} /$ day iv, Cy: 50 $\mathrm{mg} / \mathrm{kg} /$ day) and its variants in 10 and BU/Flu (BU: $0.8 \mathrm{mg} / \mathrm{kg} /$ day iv, Flu: $30 \mathrm{mg} / \mathrm{m}^{2}$ iv) and its variants in 6 patients.

\section{Statistical Analyses}

Numerical and categorical data were expressed as mean \pm standard deviation or median (range) and percentage ration, respectively. Categorical and continuous data were compared by the Chi-square (or Fisher's Exact test if required by sample size) and Independent-samples T-test, respectively. Survival analyses were computed by the Kaplan-Meier method. OS was calculated from date of transplan- 
International Journal of Hematology and Oncology

Table 1. Summary of clinical trials investigating correlations between systemic iron overload defined by serum iron tests or radiological investigations and hematopoietic stem cell transplantation related toxicities. *

\section{Clinical Conditions}

Related with

Hematopoietic

Stem Cell

Transplantation
Studies Aiming to Investigate Effect of Iron Overload or Hyperferritinemia

\begin{tabular}{|c|c|c|c|}
\hline \multicolumn{3}{|c|}{ Iron Overload } & \multirow{2}{*}{$\begin{array}{l}\text { Hyper } \\
\text { Ferritinemia }\end{array}$} \\
\hline By serum iron tests & $\begin{array}{l}\text { By } \pm \text { radiolo- } \\
\text { gical tests** }\end{array}$ & $\begin{array}{l}\text { By } \pm \text { liver } \\
\text { biopsy }\end{array}$ & \\
\hline $2,3,4,10,12,14,15,18,19,23,32$ & $1,2,3,12$ & 8 & \\
\hline
\end{tabular}

\begin{tabular}{ll}
\hline $\begin{array}{l}\text { Inadequate } \\
\text { methodology }\end{array}$ & $\begin{array}{l}\text { Adequate } \\
\text { methodology }\end{array}$ \\
\hline $4,10,12,14$, & 2,3
\end{tabular}

$15,18,19,23,31$

Increased acute

GVHD

Increased
infections
Increased
veno-occlusive
disease
Increased chronic
graft versus host
disease

$\mathrm{NI} \quad \mathrm{AO}$

$\mathrm{AO}$

14

19,23

Y

$\mathrm{NI} \quad \mathrm{AO}$

N 19

$\begin{array}{ll}Y & 10\end{array}$

$\mathrm{NI} \quad \mathrm{AO}$

N $\quad 14,19$

$\mathrm{NI} \quad \mathrm{AO}$

D

Decreased
overall survival

Decreased

disease free

survival

$\begin{array}{lll}\text { N } & 14 & 2 \\ \mathrm{Y} & 4,10,15,18,19,32 & 3 \\ \mathrm{NI} & \mathrm{AO} & \mathrm{AO}\end{array}$

14,15

10

$\mathrm{AO}$

Increased

$N$

$14,15,19$

cumulative incidence $Y$

of relapse $\quad \mathrm{NI}$

Increased cumulative N

non-relapse mortality $Y$

$\begin{array}{cc}\text { Increased treatment } & N \\ \text { related mortality } & \mathrm{Y}\end{array}$

$$
\text { N }
$$

2

3

$\mathrm{AO}$

$\mathrm{AO}$

2

$\mathrm{AO}$

2

$\mathrm{AO}$

$\mathrm{AO}$

1

$\mathrm{AO} \quad \mathrm{AO}$

1,12

8

16

$\mathrm{AO}$

$\mathrm{AO}$

$\mathrm{AO}$

1,12

8

22

$\mathrm{AO}$

$\mathrm{AO}$

$\mathrm{AO}$

16

$1,12 \quad 8$

2,3

$\mathrm{AO}$

$\mathrm{AO}$

$\mathrm{AO}$

12

$16,20,22$

$\mathrm{AO}$

$\mathrm{AO}$

12

1,12

$20,22,24$

$\mathrm{AO}$

12

1,12

$16,20,22,24$

$\mathrm{AO}$

2

$\mathrm{AO}$

8

$\mathrm{AO}$
$12,16,20,22,24$

Note: The numbers in the table represent the references of the text. * Direct iron overload-related liver toxicity was not included in this analysis. ${ }^{*}$ This methods have the handicap of missing relatively mild iron overload cases. Abbreviations: $\mathrm{N}=\mathrm{No}, \mathrm{Y}=\mathrm{Yes}, \mathrm{Nl}=$ No information, $\mathrm{AO}=$ All others, $\mathrm{D}=$ Decrease 


\begin{tabular}{|ll|}
\hline \multicolumn{2}{|l|}{ Table 2. Baseline characteristics of the patients } \\
\hline Age* $^{\star}$ & $35(17-66)$ \\
Gender (Male/Female) & $47 / 37$ \\
Type of transplant & \\
(Myeloablative/Non-myeloablative) & $17 / 67$ \\
Iron, ug/dl* & $82(25-277)$ \\
TIBC, $\mu g / d l^{*}$ & $260(81-418)$ \\
TS, \%* & 34 (7-98) \\
Ferritin, ng/ml* & 1104 (12-15000) \\
\hline * Data were given as median (minimum-maximum) value. \\
Abbreviations: TIBC= Total iron-binding capacity, TS= transferrin \\
saturation.
\end{tabular}

tation to the date of mortality of any reason. DFS was analyzed in all patients from date of transplant to relapse or death in remission. The patients who did not die and those who did not relapse or die in first CR were censored at last follow-up for OS and DFS computations, respectively. Comparisons of survival rates were done by the Log-rank test. Statistical Packages for the Social Sciences v17.0 (SPSS Inc., Chicago, IL) software was used for statistical analyses.

\section{RESULTS}

There were 84 patients suitable for inclusion. 48 patients had acute myeloid leukemia whereas 36 patients had acute lymphoblastic leukemia. The mean transferrin saturation for all patients was $42.3 \%$ and the median follow-up time for all patients was 39 months. Important baseline characteristics are presented in Table 2. 67 patients underwent nonmyeloablative HSCT, whereas 17 patients underwent myeloablative HSCT. 4, 17 and 19 patients were encountered VOD, acute and chronic GVHD, respectively. $49.8 \%$ and $51.7 \%$ were the percentages for all patients at 5 years for DFS and OS, respectively. Different elevated ferritin and transferrin saturation cut-off points were tried in order to find the point which has relationship with clinical results. When various ferritin plus TS cut-off values presented in Table 3 were investigated for a possible relationship with major transplant-related complications/results only ferritin $>2000$ plus TS

\begin{tabular}{|ll|}
\hline Table 3. Patients' results & \\
\hline TS > 45\%* & $47.6 \%$ \\
TS > 60\%* & $20.2 \%$ \\
Ferritin > 500 and TS > 45\%* & $46.4 \%$ \\
Ferritin > 1000 and TS > 45\%* & $34.5 \%$ \\
Ferritin > 1500 and TS > 45\%* & $22.6 \%$ \\
Ferritin > 2000 and TS > 45\%* & $16.6 \%$ \\
Ferritin > 2500 and TS > 45\%* & $0 \%$ \\
Acute GVHD* & $20.2 \%$ \\
Chronic GVHD* & $22.6 \%$ \\
VOD* & $4.7 \%$ \\
DFS (\% at 5 years) & $49.8 \%$ \\
OS (\% at 5 years) & $51.7 \%$ \\
Follow-up time, months & $39.0(9.0-311.2)$ \\
\hline
\end{tabular}

$>45 \%$ was found to have an association with VOD at borderline significance $(\mathrm{p}=0.067)$. There was no relationship between acute or chronic GVHD with cut-off point of ferritin $>2000$ plus TS $>45 \%$. There was no statistically significant difference between the OS and DFS times of 14 patients who satisfy the condition of "ferritin> 2000 plus TS> $45 \%$ " and 70 patients who did not satisfy the condition [ $69.6 \pm 12.5$ and $61.5 \pm 13.4$ months compared to $69.5 \pm 7.3$ and $62.5 \pm 7.2$ months, $(p=0.603$ and $\mathrm{p}=0.729)$, respectively]. The associations of this laboratory definition of iron overload with other complications/results are presented in Table 4.

\section{DISCUSSION}

The importance of iron overload in the HSCT setting had been extensively investigated in patients with thalassemia. Inadequate chelation history was found to be an important prognostic factor along with liver fibrosis and hepatomegaly. Also ferritin was suggested as a screening and monitoring tool for iron overload in thalassemia patients. ${ }^{29}$ An important difference between acute leukemia and thalassemia regarding consequences of iron overload is that acute leukemia has a much shorter disease duration which is generally insufficient to observe the clinical consequences of iron overload. Iron overload has also been suggested to play an important role in transplantation outcome for the patients with acute leukemia or myelodysplastic syndromes (MDS), as it does in thalassemia. ${ }^{10}$ Iron overload prior to transplant has been suggested to predispose to a higher rate of lethal infections. ${ }^{19,23}$ 
Table 4. The relationship between iron overload and major transplant complications

\begin{tabular}{|c|c|c|c|}
\hline \multirow{2}{*}{$\begin{array}{l}\text { Clinical } \\
\text { Conditions }\end{array}$} & \multicolumn{3}{|c|}{ Ferritin $>2000$ and $T S>45 \%$ (N:14) } \\
\hline & Yes & No & $p$ value \\
\hline Acute GVHD & 2 & 12 & 0.410 \\
\hline Chronic GVHD & 3 & 11 & 0.813 \\
\hline VOD & 2 & 12 & 0.067 \\
\hline
\end{tabular}

Note: Total 14 patients satisfy the condition of "ferritin > 2000 and TS > 45\%" in our study. These patients were investigated for associations with major transplant complications.

Abbreviations: $\mathrm{GVHD}=$ graft versus host disease, $\mathrm{VOD}=$ venoocclusive disease

A higher threshold of pre-transplant serum ferritin levels may predict HSCT outcomes. ${ }^{27}$ Pretransplantation serum ferritin may have significant prognostic value in patients with MDS undergoing myeloablative allogeneic HSCT, inducing a significant increase of non-relapse mortality. ${ }^{5}$ Thus, iron status could be considered in transplantation decision-making in MDS. Iron burden might influence toxic-infectious complications during the first 3 months after transplant in auto-transplanted patients. ${ }^{7}$ In a previous study, ferritin $>685 \mathrm{ng} /$ $\mathrm{mL}$ was associated with a higher incidence of relapse $(\mathrm{p}=0.005)$ and non-relapse mortality (NRM) $(\mathrm{p}<0.001)$, but not of non-relapse mortality $(\mathrm{p}=$ $0.23) .{ }^{30}$ Severe iron overload is associated with HSCT-related deaths and invasive aspergillosis. ${ }^{8}$ Ferritin and TS $>100 \%$ at conditioning may increase in toxic deaths after HSCT. ${ }^{9}$ When compared with myeloablative regimens, RIC regimens may attenuate the impact of iron overload related end-organ toxicity. ${ }^{15}$ The adverse impact of elevated ferritin on NRM and survival was despite its association with lower incidences of acute and chronic GVHD, which are major causes of NRM. ${ }^{16}$ Elevation of ferritin at 1 year after SCT, which may reflect transfusion and the development of chronic GVHD, may have an aggravating influence on outcomes after SCT. ${ }^{21}$

Regarding studies about iron overload in acute leukemia transplant setting, only ferritin level was used to detect iron overload in many studies. However, ferritin is an insufficient surrogate for iron overload. ${ }^{11}$ There are many conditions associated with increased serum ferritin level such as inflammation, infection, macrophage activation, liver injury, and others. Therefore, an increased ferritin level should not be considered as iron overload by itself. In some studies serum albumin level was used to eliminate the ferritin elevation as an acute phase reactant..$^{4,10,15,32}$ There is a possibility that the adverse prognostic impact of pre-HSCT hyperferritinemia may be related to factors independent of iron overload. ${ }^{12,31}$ The laboratory sign of iron overload is ferritin elevation in the presence of increased transferrin saturation.

As shown in Table 1, only two studies aiming to investigate the impact of iron overload by using serum iron tests have considered transferrin saturation. Iron overload was investigated by radiological tests in some studies. Although this method is an optimal one in apparent iron overload, it might miss iron overload in early stages. Liver biopsy was also done in one study. ${ }^{8}$ In sum, we found 5 studies which investigated the association between iron overload and post-transplant prognosis using an acceptable method (i.e. serum TS plus ferritin and/or radiological tests and/or liver biopsy) to define iron overload. ${ }^{1,2,3,8,12}$ Some of them found a relationship between iron overload and post-transplant survival. ${ }^{2,3}$ On the other hand some others did not. ${ }^{1,12}$ Interestingly the relationship between iron overload and VOD, probably the most expected specific transplant complication in patients with liver injury, was not reported in any of these studies considered to have adequate methodologies for detection of iron overload. Serum ferritin levels are being used in various clinical conditions. ${ }^{33,34}$ Also there have been some studies that were designed to search effect of hyperferritinemia irrespective of body iron status. These studies are not directly related to this study and they should be considered separately.

In conclusion, we observed a possible non-significant borderline relationship between iron overload and post-transplant veno-occlusive disease. We did not confirm other post-transplant complications reported in the literature. It must be noticed that although many studies intended to investigate the relationship between iron status and transplant outcomes, only a few of them have really looked for the effect of iron overload. 


\section{REFERENCES}

1. Trottier BJ, Burns LJ, DeFor TE, et al. Association of iron overload with allogeneic hematopoietic cell transplantation outcomes: a prospective cohort study using R2-MRI-measured liver iron content. Blood 122: 1678-1684, 2013.

2. Wermke M, Schmidt A, Middeke JM, et al. MRI-based liver iron content predicts for nonrelapse mortality in MDS and AML patients undergoing allogeneic stem cell transplantation. Clin Cancer Res 18: 6460-6468, 2012

3. Armand P, Kim HT, Rhodes J, et al. Iron overload in patients with acute leukemia or MDS undergoing myeloablative stem cell transplantation. Biol Blood Marrow Transplant 17: 852860, 2011.

4. Vaughn JE, Storer BE, Armand P, et al. Pre-Transplant Ferritin, Albumin and Platelet Count Add Prognostic Information to Comorbidities for Allogeneic Hematopoietic Cell Transplantation (HCT) Outcomes: A Multi-Center Discovery-Validation Study. Blood 124: 421, 2014.

5. Alessandrino EP, Della Porta MG, Bacigalupo A, et al. Prognostic impact of pre-transplantation transfusion history and secondary iron overload in patients with myelodysplastic syndrome undergoing allogeneic stem cell transplantation: a GITMO study. Haematologica 95: 476-484, 2010.

6. Altes A, Remacha AF, Sarda P, et al. The relationship between transferrin saturation and erythropoiesis during stem cell transplantation. Haematologica 91: 992-993, 2006.

7. Altes A, Remacha AF, Sarda P, et al. Early clinical impact of iron overload in stem cell transplantation. A prospective study. Ann Hematol 86: 443-447, 2007.

8. Altes A, Remacha AF, Sarda P, et al. Frequent severe liver iron overload after stem cell transplantation and its possible association with invasive aspergillosis. Bone Marrow Transplant 34: 505-509, 2004.

9. Altes A, Remacha AF, Sureda A, et al. Iron overload might increase transplant-related mortality in haematopoietic stem cell transplantation. Bone Marrow Transplant 29: 987-989, 2002.

10. Armand P, Kim HT, Cutler CS, et al. Prognostic impact of elevated pretransplantation serum ferritin in patients undergoing myeloablative stem cell transplantation. Blood 109: 45864588, 2007.

11. Armand P, Kim HT, Virtanen JM, et al. Iron overload in allogeneic hematopoietic cell transplantation outcome: a metaanalysis. Biol Blood Marrow Transplant 20: 1248-1251, 2014.

12. Armand P, Sainvil MM, Kim HT, et al. Does iron overload really matter in stem cell transplantation? Am J Hematol 87: 569572, 2012.

13. Armand P, Sainvil MM, Kim HT, et al. Pre-transplantation iron chelation in patients with MDS or acute leukemia and iron overload undergoing myeloablative allo-SCT. Bone Marrow Transplant 48: 146-147, 2013.

14. Efebera YA, Thandi RS, Saliba RM, et al. The Impact of PreStem Cell Transplant Ferritin Level on Late Transplant Complications: An Analysis to Determine the Potential Role of Iron Overload on Late Transplant Outcomes. Internet J Hematol 7: 9127, 2009.

UHOD Number: 1 Volume: 26 Year: 2016
15. Lim ZY, Fiaccadori V, Gandhi S, et al. Impact of pre-transplant serum ferritin on outcomes of patients with myelodysplastic syndromes or secondary acute myeloid leukaemia receiving reduced intensity conditioning allogeneic haematopoietic stem cell transplantation. Leuk Res 34: 723-727, 2010.

16. Mahindra A, Bolwell B, Sobecks R, et al. Elevated pretransplant ferritin is associated with a lower incidence of chronic graft-versus-host disease and inferior survival after myeloablative allogeneic haematopoietic stem cell transplantation. $\mathrm{Br} J$ Haematol 146: 310-316, 2009.

17. Mahindra A, Sobecks R, Rybicki L, et al. Elevated pretransplant serum ferritin is associated with inferior survival following nonmyeloablative allogeneic transplantation. Bone Marrow Transplant 44: 767-768, 2009.

18. Oakes R, Sood N, Pearce R, et al. Prognostic impact of serum ferritin concentration on survival following reduced-intensity conditioned allogeneic haemopoietic SCT. Bone Marrow Transplant 45: 1754-1755, 2010.

19. Storey JA, Connor RF, Lewis ZT, et al. The transplant iron score as a predictor of stem cell transplant survival. J Hematol Oncol 2: 44, 2009.

20. Tachibana T, Takasaki H, Tanaka M, et al. Serum ferritin and disease status at transplantation predict the outcome of alloSCT in patients with AML or myelodysplastic syndrome. Bone Marrow Transplant 46:150-151, 2011.

21. Tachibana T, Tanaka M, Numata A, et al. Clinical significance of pre- and 1-year post-transplant serum ferritin among adult transplant recipients. Leuk Lymphoma 55: 1350-1356, 2014.

22. Tachibana T, Tanaka M, Numata A, et al. Pretransplant serum ferritin has a prognostic influence on allogeneic transplant regardless of disease risk. Leuk Lymphoma 53: 456-461, 2012.

23. Tachibana T, Tanaka M, Takasaki H, et al. Pretransplant serum ferritin is associated with bloodstream infections within 100 days of allogeneic stem cell transplantation for myeloid malignancies. Int J Hematol 93: 368-374, 2011.

24. Tachibana T, Tanaka M, Takasaki H, et al. Pre-SCT serum ferritin is a prognostic factor in adult AML, but not ALL. Bone Marrow Transplant 46: 1268-1269, 2011.

25. Tachibana T, Tanaka M, Yamazaki E, et al. Multicenter validation of scoring system of pre-transplant serum ferritin and disease risk in patients with acute myeloid leukemia and myelodysplastic syndrome after allogeneic hematopoietic stem cell transplant. Leuk Lymphoma 54: 1318-1320, 2013.

26. Takasaki H, Tanaka M, Tachibana T, et al. Prognostic factors in patients aged 50 years or older undergoing allogeneic hematopoietic stem cell transplantation for hematologic malignancy. Int J Hematol 95: 291-298, 2012.

27. Tanaka M, Kanamori $H$, Matsumoto $K$, et al. Clinical significance of pretransplant serum ferritin on the outcome of allogeneic hematopoietic SCT: a prospective cohort study by the Kanto Study Group for Cell Therapy. Bone Marrow Transplant 50: 727-733, 2015.

28. Tanaka M, Tachibana T, Numata A, et al. A prognostic score with pretransplant serum ferritin and disease status predicts outcome following reduced-intensity SCT. Bone Marrow Transplant 47: 596-597, 2012. 
29. Shah R, Trehan A, Das R, Marwaha RK. Serum ferritin in thalassemia intermedia. Indian $\mathrm{J}$ Hematol Blood Transfus 30: 281-285, 2014.

30. Mahindra A, Bolwell B, Sobecks R, et al. Elevated ferritin is associated with relapse after autologous hematopoietic stem cell transplantation for lymphoma. Biol Blood Marrow Transplant 14: 1239-1244, 2008.

31. Knovich MA, Storey JA, Coffman LG, et al. Ferritin for the clinician. Blood Rev 23: 95-104, 2009.

32. Artz AS, Logan BR, Zhu X, et al. Pre-Transplant C-Reactive Protein (CRP), Ferritin and Albumin As Biomarkers to Predict Transplant Related Mortality (TRM) after Allogeneic Hematopoietic Cell Transplant (HCT). Blood 124: 422, 2014.

33. Keramati MR, Siadat Z, Mahmoudi M. The Correlation Between $\mathrm{H}$. Pylori Infection with Serum Ferritin Concentration and Iron Deficiency Anemia. UHOD 25: 16-20, 2015.

34. Erbaycu AE, Ucar H, Gulpek M, et al. The Contribution of Serum Ferritin, Iron, Iron Binding Capacity and Bronchoalveolar Lavage Ferritin Levels in Differential Diagnosis of Lung Cancer from Benign Pulmonary Diseases. UHOD 25: 129-137, 2015.

\section{Correspondence}

Dr. Ümit Yavuz MALKAN

Hacettepe Üniversitesi Tip Fakültesi

Hematoloji Anabilim Dali

Sihhiye, ANKARA / TURKEY

Tel: (+90-532) 7780087

Fax: (+90-312) 3051614

e-mail: umitmalkan@hotmail.com 